\title{
Cow's milk allergy: Evaluating tolerance through skin-prick test
}

\author{
Flavia Valença de Oliveira Neves ${ }^{1}$, Clegonir de Moraes lui Beck ${ }^{1}$, Andrea Keiko Fujinami Gushken ${ }^{1}$, Glauce Hiromi Yonamine ${ }^{2}$, \\ ana Paula Beltran Moschione Castro ${ }^{3}$, Mayra de Barros Dorna ${ }^{1}$, Cristiane de Jesus Nunes dos Santos ${ }^{4}$, \\ Antonio Carlos Pastorino ${ }^{5 *}$ \\ ${ }^{1}$ MSc from Faculdade de Medicina, Universidade de São Paulo (FMUSP). Unit of Allergy and Immunology, Department of Pediatrics, FMUSP, São Paulo, SP, Brazil \\ ${ }^{2}$ MSc from FMUSP. Division of Nutrition, Hospital das Clínicas, FMUSP, São Paulo, SP, Brazil \\ ${ }^{3} \mathrm{MSc}$ and PhD in Sciences from FMUSP. Unit of Allergy and Immunology, Department of Pediatrics, FMUSP, São Paulo, SP, Brazil \\ ${ }^{4}$ Assistant, Unit of Allergy and Immunology, Department of Pediatrics, FMUSP, São Paulo, SP, Brazil \\ ${ }^{5} \mathrm{MSc}$ and PhD in Sciences from FMUSP. Head of the Unit of Allergy and Immunology, Department of Pediatrics, FMUSP, São Paulo, SP, Brazi
}

\footnotetext{
Study conducted at the Unit of Allergy and Immunology, Department of Pediatrics, and the Division of Nutrition, Hospital das Clínicas, Faculdade de Medicina, Universidade de São Paulo (HC-FMUSP), São Paulo, SP, Brazil

Article received: $6 / 29 / 2016$ Accepted for publication: 7/26/2016

*Correspondence: Address: Rua Dr. João Batista Soares de Faria, 113, apto. 141, Santana São Paulo, SP - Brazil Postal code: 02403-050 acpastorino@uol.com.br

http://dx.doi.org/10.1590/1806-9282.62.06.537 Financial support: MSc grant - Capes
}

\section{SUMmARY}

Objective: To evaluate the wheal diameter in allergy skin-prick tests (SPT) with cow's milk extract $(\mathrm{CM})$ comparing tolerant and persistent patients.

Method: A retrospective cohort study involving database analysis of children with diagnosis of cow's milk protein allergy (CMPA) mediated by immunoglobulin E in a specialized outpatient clinic that regularly performed SPT between January 2000 and July 2015. Patients were allocated into two groups: tolerant or persistent. Comparisons were made at diagnosis and over time between tolerant and persistent patients using Fisher's, Mann-Whitney or Wilcoxon tests and significance level at 5\%. Results: After applying inclusion and exclusion criteria, the sample includes 44 patients ( 29 tolerant and 15 who persisted with CMPA). In the tolerant group, the medians of SPT were: $6 \mathrm{~mm}$ at diagnosis and $2 \mathrm{~mm}$ at the development of tolerance; a significant difference $(\mathrm{p}<0.0001)$ was found. In the persistent group, the median SPT at diagnosis was $7 \mathrm{~mm}$, while in the last SPT it was $5 \mathrm{~mm}$, with no statistical difference $(\mathrm{p}=0.173)$. The comparison of medians in the last SPT between groups was significant $(\mathrm{p}=0.001)$, with a reduction greater than $50 \%$ in SPT in the tolerant group.

Conclusion: Serial SPTs were useful for diagnosis, and a decrease higher than 50\% in diameter can indicate the moment to perform oral food challenge (OFC) tests, helping to detect tolerance in CMPA.

Keywords: food hypersensitivity, immediate hypersensitivity, hypersensitivity to milk/diagnosis, immune tolerance, child, preschooler.

\section{INTRODUCTION}

The increased prevalence of food allergy (FA) is a reality throughout the world, presenting more severe reactions and resolution at a later age. ${ }^{1-5}$ The natural history of cow's milk protein allergy (CMPA) described until the 2000s showed that allergy would develop early, with resolution in the first years of life. ${ }^{6-8}$ More recently, Skripak et al. ${ }^{1}$ reported in 2007 that $21 \%$ of the children with CMPA remained allergic up to the age of 16 years.

Diagnosis of IgE-mediated CMPA is based on a combination of compatible clinical history and specific IgE testing to cow's milk (CM), either by in vivo skin-prick testing (SPT) and/or in vitro search for specific serum IgE $\left(\right.$ ImmunoCAP ${ }^{\circledR}$ ) to $\mathrm{CM}$ and its fractions. In addition, when indicated, oral food challenge (OFC) tests with the suspected food should be conducted, which is considered the gold standard for the diagnosis of FA., 10

In a reference center for food allergy, Jacob et al. ${ }^{11}$ in 2009 showed that only $45 \%$ of patients were tolerant at the age of 5 years. Risk factors associated with the persistence of IgE-mediated CMPA were considered: presence of anaphylaxis, sensitization to other foods, high concentration of total IgE and specific IgE to CM and casein with cutoff points over than $4.88 \mathrm{kU} / \mathrm{L}$ and $3.5 \mathrm{kU} / \mathrm{L}$, respectively. ${ }^{11}$

Many studies suggest cutoff values for SPT that support the diagnosis of FA but, so far, there are few studies evaluating test results to define tolerance, and none from 
Brazil. ${ }^{4}$ Determining values for SPT to CM associated with tolerance and/or percentage of decrease in values could be useful for earlier indication of OFC with that food, avoiding prolonged restrictive diets and other risks for patients with CMPA.

The objectives of this study were: to compare SPT wheal diameters with $\mathrm{CM}$ extract between patients of the tolerant and persistent groups at diagnosis and at the time of tolerance acquisition, and to compare the variation of SPT wheal diameters in the tolerant and persistent groups.

\section{Method}

A retrospective cohort study involving database analysis of medical charts of all children with confirmed diagnosis of immunoglobulin E-mediated CMPA (CMPA-IgE) who underwent SPT serially, being allocated into one of two groups: CMPA tolerant and CMPA persistent. All patients negative to OFC in the clinical follow-up were considered CMPA tolerant.

Medical charts of 445 patients being followed up by the Unit of Allergy and Immunology of Instituto da Criança, HC-FMUSP, between January 2000 and July 2015 were assessed regarding clinical history, family and personal history of atopy, clinical manifestations associated with CMPA, and specific IgE dosage to cow's milk on ImmunoCAP ${ }^{\circledR}$. The following inclusion criteria were used: Confirmed diagnosis of CMPA defined based on suggestive history of CMPA associated with the presence of positive specific IgE, as well as OFC showing reactivity to CM (except in patients with a history of anaphylaxis) and at least three SPT over the follow-up period. Exclusion criteria included: patients lost to follow-up; patients with recent anaphylaxis caused by cow's milk protein but who did not undergo SPT to this allergen and patients with non-IgE-mediated CMPA.

The analysis included only SPTs made with cow's milk extract from the same source (FDA Allergenic ${ }^{\circledR}$ $\mathrm{RJ})$, throughout the study period, using a standard technique. Individual disposable plastic lancets were used (Alko do Brasil, Rio de Janeiro, Brazil) and reading was performed 15 minutes later by measuring the largest perpendicular diameters and calculating the mean diameter. Results were positive if mean wheal diameter $\geq$ $3 \mathrm{~mm}$ compared to negative controls. ${ }^{12}$ In patients undergoing a minimum of three SPT during follow-up until development of tolerance, the percentage change of the wheal diameter observed in SPT at diagnosis and at the development of tolerance was assessed. A group of patients who did not develop tolerance to CM but had at least three evolutive SPTs until completion of the study was also included.

This study was approved by the Ethics Committee for Hospital Research Project Analysis of the FMUSP (CAPPesq) under number 9449/2012.

Data were analyzed using Statistical Package for Social Sciences (SPSS) 13.0 and MedCalc Statistical Software 15.8 .

After normal distribution analysis using Shapiro-Wilk test, the nominal variables: gender, family history of atopy, use of cow's milk in the nursery, breastfeeding for less than 6 months, and the presence of other allergic diseases were described by frequencies and compared between tolerant and persistent patients based on the Fisher's exact or Mann-Whitney test. Continuous variables (age at onset symptoms and at the collection of data, and specific IgE levels to cow's milk by ImmunoCAP ${ }^{\circledR}$ ) in the same groups were described by medians and compared using Mann-Whitney and Wilcoxon test.

SPT results (in $\mathrm{mm}$ ) were described as medians and minimum and maximum values at diagnosis and at the end of the study, both in the tolerant and persistent group. Comparisons at each time were performed using Mann-Whitney test.

The reduction in median SPT to CM from diagnosis to the time point of tolerance in the tolerant group, and from diagnosis to the last SPT performed by the end of the study in the persistent group was assessed using Wilcoxon test.

In all analyzes, the considered significance level was 5\%.

\section{Results}

Once the inclusion and exclusion criteria were applied, our sample totaled 44 patients, 29 in the group that developed tolerance, and 15 in the group that persisted with CMPA by the end of the study.

Table 1 summarizes the epidemiological and clinical characteristics, and ImmunoCAP ${ }^{\circledR}$ results of the patients included, with no statistically significant difference between the groups, except for a history of anaphylaxis more frequent among persistent patients and ImmunoCAP® values for cow's milk higher in that group.

In the tolerant group, 11 patients (37.9\%) developed tolerance up to the age of 5 years, and 18 patients (62.1\%) developed tolerance after 5 years of age.

Regarding the ImmunoCAP ${ }^{\circledR}$ results at baseline for $\mathrm{CM}$, there was a statistically significant difference between the tolerant group (median $=4.39 \mathrm{kU} / \mathrm{L}$, ranging from 0.53 to $100 \mathrm{kU} / \mathrm{L}$ ) compared with the persistent group $($ median $=24.1 \mathrm{kU} / \mathrm{L}$, ranging from 8.78 to $100 \mathrm{kU} / \mathrm{L})$ with $\mathrm{p}=0.0003$ (Wilcoxon test). 


\begin{tabular}{|c|c|c|c|}
\hline Variable & $\begin{array}{l}\text { Tolerant patients } \\
n=29(\%)\end{array}$ & $\begin{array}{l}\text { Persistent patients } \\
n=15(\%)\end{array}$ & $\mathbf{p}$ \\
\hline Gender & 19 & 10 & $1.00^{*}$ \\
\hline \multicolumn{4}{|l|}{ Male } \\
\hline Current age (years) & 5.4 & 8.0 & $0.08 * *$ \\
\hline Median (min-max) & $(1.9-17.9)$ & $(3.7-13.9)$ & \\
\hline Family history of atopy & $20(68.9)$ & $12(80)$ & $0.500^{*}$ \\
\hline Personal history of atopy & $23(79.3)$ & $10(66.7)$ & $0.468^{*}$ \\
\hline Did not use $\mathrm{CM}$ while in the nursery & $15(51.7)$ & $10(66.7)$ & $0.522^{*}$ \\
\hline Breastfed for $<6$ months & $24(82.7)$ & $15(100)$ & $0.149^{*}$ \\
\hline Age at onset of symptoms (days) & 120 & 120 & $0.736 * *$ \\
\hline Median (min-max) & $(1-300)$ & $(7-300)$ & \\
\hline Atopic dermatitis & $4(13.8)$ & $2(13.3)$ & $1.000^{*}$ \\
\hline Anaphylaxis & $12(41.4)$ & $13(86.7)$ & $0.0048^{*}$ \\
\hline ImmunoCAP ${ }^{\oplus}$ for $\mathrm{CM}(\mathrm{kU} / \mathrm{L})$ & 4.39 & 24.1 & $0.0003^{\#}$ \\
\hline Median (min-max) & $(0.53-100)$ & $(8.78-100)$ & \\
\hline
\end{tabular}

CM: cow's milk.

*Fisher's test; ** Mann-Whitney; ${ }^{*}$ Wilcoxon test.

In the tolerant group, the following SPT measures were found at diagnosis: median of $6 \mathrm{~mm}(3-15 \mathrm{~mm})$. As for the development of tolerance, the measures found were: median $2 \mathrm{~mm}(0-5 \mathrm{~mm})$ (Figure 1A). There was a statistically significant difference between the values with $\mathrm{p}<0.0001$ (Wilcoxon test), and a reduction greater than $50 \%$ in SPT values.

In the group of patients persistent to CMPA, the following measures of SPT were found, respectively: median of $7 \mathrm{~mm}(3-13 \mathrm{~mm})$ at diagnosis; and median of 5 $\mathrm{mm}(0-19 \mathrm{~mm})$ at the time point of the last SPT performed until the end of the study (Figure 1B), with no statistically significant difference between the two measures and $\mathrm{p}$-value $=0.173$ (Wilcoxon test).

The comparison of the medians of SPT values between groups of tolerant and persistent patients at diagnosis showed no statistically significant difference, p-val$\mathrm{ue}=0.342$ (Mann-Whitney test). The comparison of the medians of the last SPT values obtained from both groups (Figure 2) detected a statistically significant difference between groups, with $\mathrm{p}=0.001$ (Mann-Whitney test).

\section{Discussion}

Skin tests to cow's milk are easy, fast and safe to be performed, and are an important tool for the diagnosis of CMPA. Furthermore, when performed serially, they can help determine the best time for indicating OFC and thus define the patient as tolerant or persistent.
Considering as a retrospective analysis of medical records, only 44 children met the inclusion criteria, as many had not undergone three or more SPTs using cow's milk extract from the same supplier.

Presence of anaphylaxis was the only clinical aspect that showed significant differences between persistent and tolerant groups (Table 1), as previously shown in the same service by Jacob et al. ${ }^{2}$ Atopic dermatitis had no significant influence on this difference, as described by Payot et al..$^{13}$ Factors previously described such as asthma and allergies to other foods were identified as independent predictors for persistent CMPA after the age of 2 years, ${ }^{14}$ not observed in the present study.

Another relevant aspect of this study was to demonstrate that, among patients with CMPA treated at an outpatient clinic specializing in food allergy, the development of tolerance occurred after the age of 5 years in most patients, confirming the data presented in the literature in the last years. Jacob et al., in 2010, evaluating patients with CMPA from the same service, identified that $45 \%$ of the individuals were tolerant by the age of 5 years; in our sample, we found that the rate of resolution in the same age range fell to $37.9 \%$. In 2010, Santos et al. ${ }^{14}$ found tolerance in only $22 \%$ of the children aged up to 5 years. Skripak et al., ${ }^{1}$ in 2007 , found that $21 \%$ of the children with CMPA persisted allergic up to the age of 16 years.

SPT is a very important test in IgE-mediated allergies and must always be interpreted considering the clinical 
history. ${ }^{15}$ It is easy to perform, most cost-effective, reliable, minimally invasive, safe, and provides immediate and reproducible results. It must be performed by a specialist because, though rare, systemic reactions may occur. SPTs can be performed at any age but patients younger than 2 and older than 65 years may have smaller papules because skin reactivity acquired during childhood reaches peak between 15 and 25 years and declines progressively. ${ }^{12}$

It is important to know that allergenic extracts could have different composition and potency. Extracts from different laboratories cause discrepancies in the interpretation of results. ${ }^{16}$ Because some food proteins are
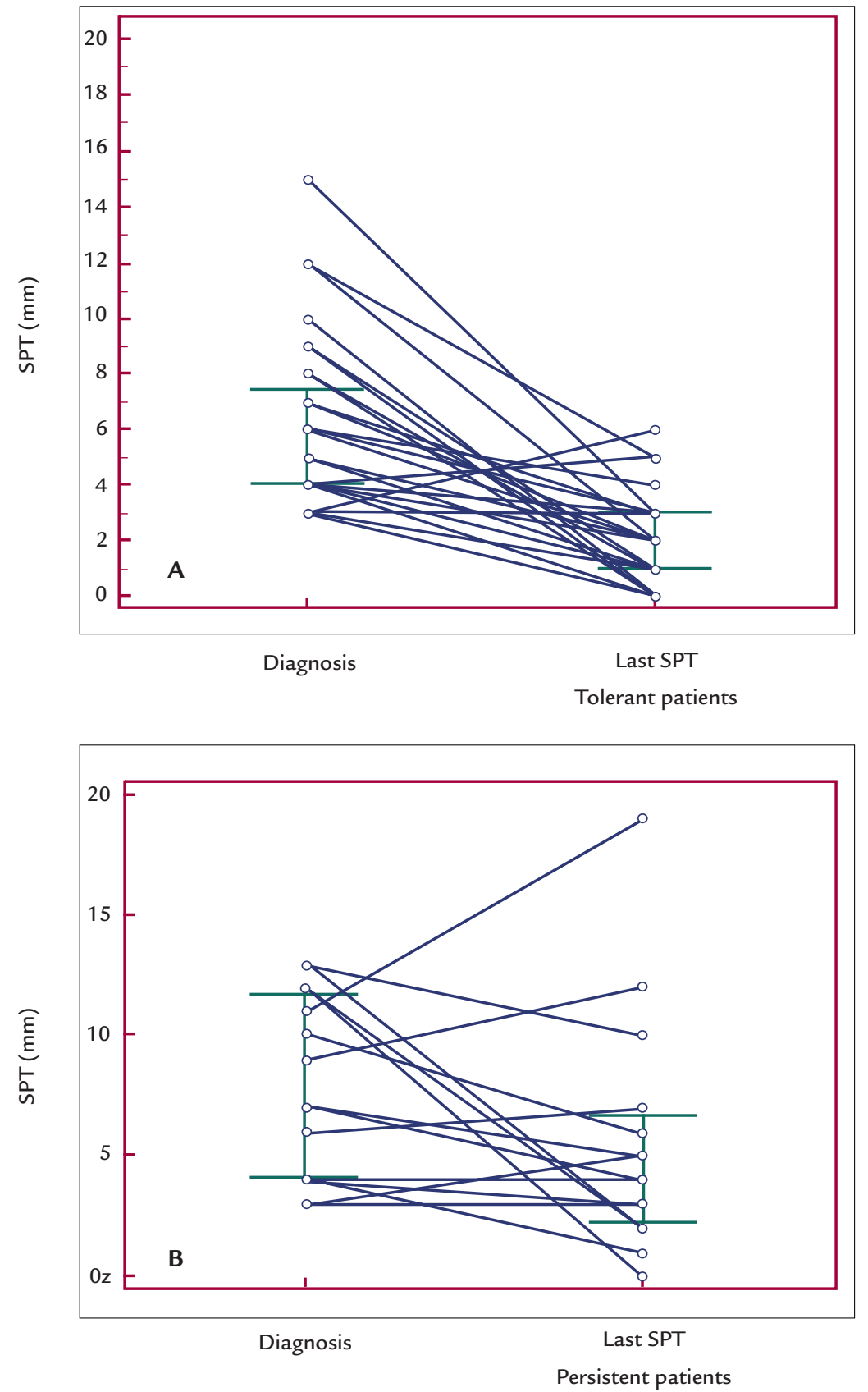

FIGURE 1 A: Decline of SPT wheal size to cow's milk (in $\mathrm{mm}$ ) in the group of tolerant patients ( $\mathrm{n}=29$ ) at diagnosis and at the time point of tolerance $(p<0.0001)$. B: Decline of SPT wheal size to cow's milk (in mm) in the group of persistent patients $(n=15)$ at diagnosis and at the last SPT carried out $(p=0.173)$. 


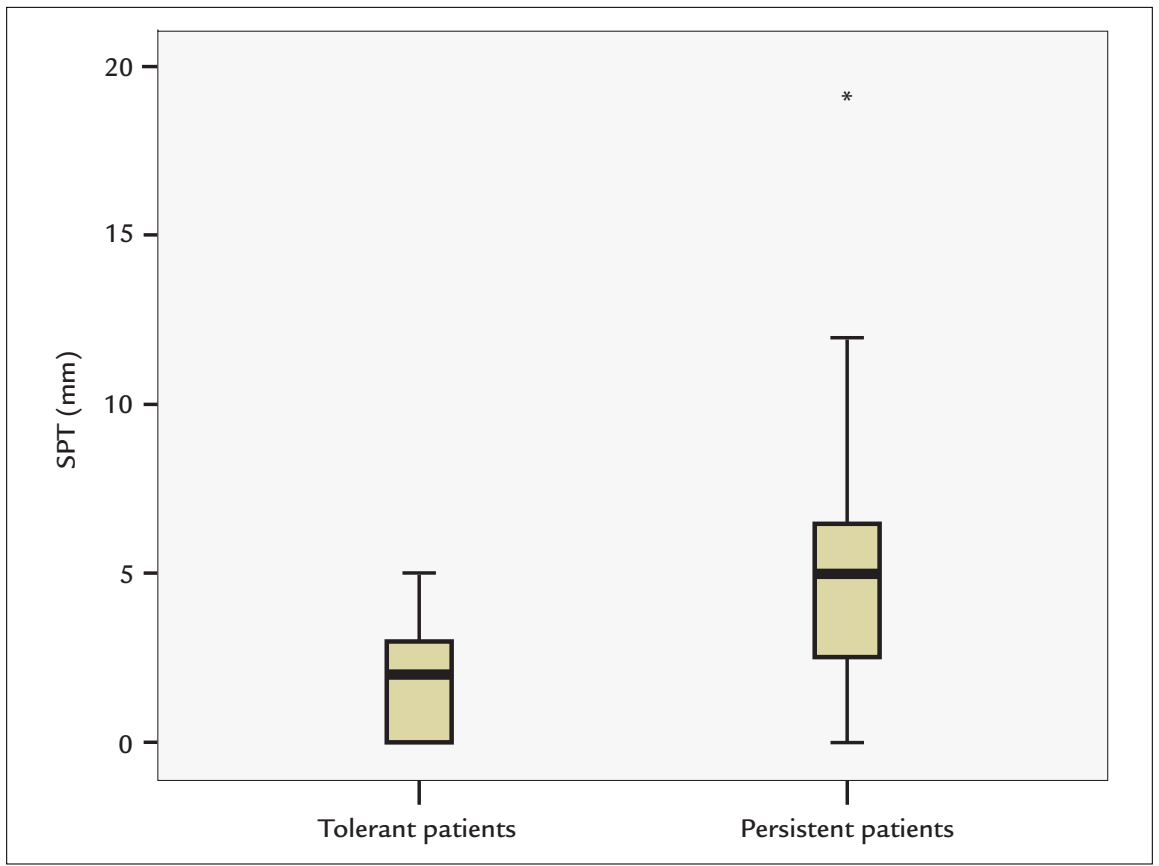

FIGURE 2 Comparison of median values for the last SPT to cow's milk (in mm), both among tolerant and persistent patients ( $p=0.001$ ).

unstable, commercial extracts may be ineffective, and SPT can be performed with fresh food, more related to OFC when compared to commercial extracts $(91.7 \% v s$. $58.8 \%$ ). In the same study, however, the authors demonstrated that SPT using fresh CM did not result in wheal diameters significantly larger than those obtained from commercial extracts. ${ }^{17}$

In our study, we evaluated SPT using only a commercial extract of whole CM, not including CM fractions, since superiority of specific IgE analysis of CM for diagnosis compared to casein has already been demonstrated in the same service, although the values assessed were serum specific IgE. ${ }^{18}$ In addition, a previous study by Watanabe et al. conducted in the same outpatient clinic had already demonstrated that there are no differences between SPT methods and serum dosages of specific $\operatorname{IgE} .^{19}$

The cutoff values for SPT as presented in the 2014 guideline for CMPA diagnosis show several authors describing wheal diameters equal to $3 \mathrm{~mm}$ for fresh $\mathrm{CM}$ as positive predictive values (PPV), with specificity ranging from 50 to $100 \%$, which demonstrates the great variability of results in these studies. ${ }^{20-23}$ Other authors showed wheal diameters for fresh CM between 6 to $15 \mathrm{~mm}$, varying with age. ${ }^{24-27}$

In the tolerant and persistent groups, median SPT to $\mathrm{CM}$ at diagnosis was $6 \mathrm{~mm} v \mathrm{~s} .7 \mathrm{~mm}$, with no statistical significant difference $(\mathrm{p}=0.342)$. Considering the last performed SPT, there was a significant difference between tolerant and persistent patients $(\mathrm{p}=0.001)$. This demonstrates the importance of evolutive analysis of the SPT, which presents progressive decay in the tolerant group unlike the persistent group. Statistically significant SPT values for tolerance, investigated in 178 children and confirmed by OFC, were found by Payot et al., corresponding to 2.2 in tolerant $v s .5 .1 \mathrm{~mm}$ in persistent patients, results very similar to our data. ${ }^{13}$

SPT has been used for decades to prove or rule out sensitization to allergens. Negative SPT results are used to confirm the absence of IgE-mediated reaction, with negative predictive value (NPV) exceeding $95 \%$. This test's PPV, however, reaches approximately $50 \%$, often requiring OFC to confirm the diagnosis. ${ }^{28,29}$ Therefore, it is not possible to set SPT values to be widely used for diagnosis of CMPA, which also applies to establish tolerance.

The inclusion of patients with at least three SPT was based on the lack of results in the literature showing the time point in the follow-up of patients with CMPA in which tolerance could be established and CM promptly reintroduced to the diet. That would liberate the patients and their families from the anxiety and difficulties related to a restrictive diet for children and adolescents.

The main limitation of our study is sample size, which did not allow the development of a ROC curve as performed by Payot et al. ${ }^{13}$

When we analyze the values of median SPT at diagnosis and at the time of tolerance acquisition, there was a de- 
cline of over $50 \%$ ( $6 \mathrm{~mm} v \mathrm{~s} .2 \mathrm{~mm}$ ), which may be indicative of OFC to confirm CMP tolerance associated with a favorable clinical outcome. We did not find in the literature values comparable to our results. On the other hand, in the persistent group, the decline was lower than 50\% (7 $\mathrm{mm} v s .5 \mathrm{~mm}$ ), suggesting that the moment was not ideal to perform an OFC. In a recent publication by Payot et al., ${ }^{13}$ the authors found a probability of $80 \%$ of negative OFC with SPT wheal size equal to zero, specific IgE for $\mathrm{CM}$ at $0.85 \mathrm{kU} / \mathrm{L}$ and $\mathrm{IgE}$ to casein for $0.73 \mathrm{kU} / \mathrm{L}$, values that can be difficult to achieve in clinical practice.

\section{Conclusion}

The use of SPT for diagnosis and to predict the presence of tolerance in cases of CMPA is useful and can be performed serially along the CMPA progression, favoring indication of a more appropriate time to perform OFC when its values are reduced by at least $50 \%$. Regional studies with larger numbers of patients will allow more accurate results to indicate the best time to carry out an OFC, avoiding dietary restrictions for a prolonged time.

\section{ACKNOWLEDGMENTS}

Dr. Cristina MA Jacob for the creation of the Food Allergy Outpatient Clinic, and for constantly inspiring us to overcome our challenges at the Unit of Allergy and Immunology; and Dr. Ulysses Doria Filho for the help with the statistical part of the project.

\section{Resumo}

Alergia ao leite de vaca: avaliação da tolerância pelo teste cutâneo alérgico

Objetivo: avaliar o diâmetro da pápula do teste cutâneo alérgico (TCA) com extrato de leite de vaca (LV) comparando pacientes tolerantes e persistentes.

Método: estudo de coorte retrospectivo de análise de banco de dados de crianças com diagnóstico de alergia à proteína do leite de vaca (APLV) mediada pela imunoglobulina E, em ambulatório especializado, que realizaram TCA de forma evolutiva, sendo alocados em dois grupos: tolerantes ou persistentes, entre janeiro de 2000 e julho de 2015. As comparações foram realizadas ao diagnóstico e evolutivamente entre tolerantes e persistentes, pelos testes de Fisher, Mann-Whitney ou Wilcoxon, utilizando níveis de significância de $5 \%$.

Resultados: aplicando critérios de inclusão e exclusão, a amostra incluiu 44 pacientes (29 tolerantes e 15 que persistiram com APLV). No grupo tolerante, as medianas do
TCA foram: ao diagnóstico, de $6 \mathrm{~mm}$, e, no desenvolvimento de tolerância, de $2 \mathrm{~mm}$, com diferença significante $(\mathrm{p}<0,0001)$. No grupo persistente, a mediana do TCA ao diagnóstico foi de $7 \mathrm{~mm}$ e no momento do último TCA, de $5 \mathrm{~mm}$, sem diferença estatística $(\mathrm{p}=0,173)$. A comparação das medianas no último TCA entre os grupos mostrou-se significante ( $\mathrm{p}=0,001)$, com redução maior de $50 \%$ no valor do TCA no grupo tolerante.

Conclusão: os TCA seriados foram úteis para o diagnóstico, e a redução maior que $50 \%$ em seu diâmetro pode indicar o momento para realização de testes de provocação oral (TPO), auxiliando na detecção de tolerância na APLV.

Palavras-chave: hipersensibilidade alimentar, hipersensibilidade imediata, hipersensibilidade a leite/diagnóstico, tolerância imunológica, criança, pré-escolar.

\section{References}

1. Skripak JM, Matsui EC, Mudd K, Wood RA. The natural history of IgEmediated cow's milk allergy. J Allergy Clin Immunol. 2007; 120(5):1172-7.

2. Jacob CMA, Oliveira CL, Pastorino AC, Goldberg AC, Okay TS, Fomin ABF, et al. Is there a specific profile of patients with persistent IgE-mediated cow's milk allergy? J Allergy Clin Immunol. 2010; 125(2):AB24.

3. Gupta RS, Springston EE, Warrier MR, Smith B, Kumar R, Pongracic J, et al. The prevalence, severity, and distribution of childhood food allergy in the United States. Pediatrics. 2011; 128(1):8-17.

4. Luyt D, Ball H, Makwana N, Green MR, Bravin K, Nasser SM, et al.; Standards of Care Committee (SOCC) of the British Society for Allergy and Clinical Immunology (BSACI). BSACI guideline for the diagnosis and management of cow's milk allergy. Clin Exp Allergy. 2014; 44(5):642-72.

5. Nwaru BI, Hickstein L, Panesar SS, Roberts G, Muraro A, Sheikh A; EAACI Food Allergy and Anaphylaxis Guidelines Group. Prevalence of common food allergies in Europe: a systematic review and meta-analysis. Allergy. 2014; 69(8):992-1007.

6. Høst A. Frequency of cow's milk allergy in childhood. Ann Allergy Asthma Immunol. 2002; 89(6 Suppl 1):33-7.

7. Høst A. Cow's milk protein allergy and intolerance in infancy. Some clinical, epidemiological and immunological aspects. Pediatr Allergy Immunol. 1994; 5(5 Suppl):1-36.

8. Sampson HA. Food allergy. Part 1: immunopathogenesis and clinical disorders. J Allergy Clin Immunol. 1999; 103(5 Pt 1):717-28.

9. Rona RJ, Keil T, Summers C, Gislason D, Zuidmeer L, Sodergren E, et al. The prevalence of food allergy: a meta-analysis. J Allergy Clin Immunol. 2007; 120(3):638-46.

10. Gushken AK, Castro AP, Yonamine GH, Corradi GA, Pastorino AC, Jacob CM. Double-blind, placebo-controlled food challenges in Brazilian children: adaptation to clinical practice. Allergol Immunopathol (Madr). 2013; 41(2):94-101.

11. Jacob CMA, Pastorino AC, Fomin ÂBF, Watanabe LA, Fucci VZ, Gushken $\mathrm{AKF}$, et al. Prognostic factors associated to persistent IgE-mediated cow's milk allergy (CMA). J Allergy Clin Immunol. 2009; 123(2): S179.

12. Heinzerling L, Mari A, Bergmann KC, Bresciani M, Burbach G, Darsow U, et al. The skin prick test - European standards. Clin Transl Allergy. 2013; 3(1):1-10.

13. Payot F, Berthiller F, Kassai B, Brunet A-S, Villard-Truc F, Lachaux F. Practical interest of both skin prick test and specific $\operatorname{IgE}$ in the evaluation of tolerance acquisition in IgE mediated cow's milk allergy (CMA). A clinical retrospective study in a cohort of 184 children. Allergol Immunopathhol (Madr). 2014; 42(5):395-401.

14. Santos A, Dias A, Pinheiro JA. Predictive factors for persistence of cow's milk allergy. Pediatr Allergy Immunol. 2010; 21(8):1127-34.

15. Eigenmann PA, Oh JW, Beyer K. Diagnostic testing in the evaluation of food allergy. Pediatr Clin N Am. 2011; 58(2):351-62. 
16. Bernstein IL, Li JT, Bernstein DI, Hamilton R, Spector SL, Tan R, et al.; American Academy of Allergy, Asthma and Immunology; American College of Allergy, Asthma and Immunology. Allergy diagnostic testing: an updated practice parameter. Ann Allergy Asthma Immunol. 2008; 100(3 Suppl 3):S1-148.

17. Rancé F, Juchet A, Bremont F, Dutau G. Correlations between skin prick tests using commercial extracts and fresh foods, specific IgE, and food challenges. Allergy. 1997; 52(10):1031-5.

18. Castro AP, Pastorino AC, Gushken AK, Kokron CM, Filho UD, Jacob CMA Establishing a cut-off for the serum levels of specific IgE to milk and its components for cow's milk allergy: Results from a specific population. Allergol Immunopathol (Madr). 2015; 43(1):67-72.

19. Watanabe LA, Beck CM, Higa M, Gushken AK, Yonamine GH, Fomin AB Castro AP, Pastorino AC, Jacob CM. Comparação entre ImmunoCAP® e teste cutâneo de hipersensibilidade imediata na avaliação da alergia às proteínas do leite de vaca IgE mediada em crianças. Rev Bras Alerg Imunopatol. 2010; 33(6):224-8.

20. Sampson HA, Ho DG. Relationship between food-specific IgE concentrations and the risk of positive food challenges in children and adolescents. J Allergy Clin Immunol. 1997; 100(4):444-51.

21. García-Ara C, Boyano-Martínez T, Díaz-Pena JM, Martín-Muñoz F, RecheFrutos M, Martín-Esteban M. Specific IgE levels in the diagnosis of immediate hypersensitivity to cows' milk protein in the infant. J Allergy Clin Immunol. 2001; 107(1):185-90.
22. Osterballe M, Andersen KE, Bindslev-Jensen C. The diagnostic accuracy of the atopy patch test in diagnosing hypersensitivity to cow's milk and hen's egg in unselected children with and without atopic dermatitis. J Am Acad Dermatol. 2004; 51(4):556-62.

23. Calvani M, Alessandri C, Frediani T, Lucarelli S, Miceli Sopo S, Panetta V, et al. Correlation between skin prick test using commercial extract of cow's milk protein and fresh milk and food challenges. Pediatr Allergy Immunol. 2007; 18(7):583-8.

24. Sporik R, Hill DJ, Hosking CS. Specificity of allergen skin testing in predicting positive open food challenges to milk, egg and peanut in children. Clin Exp Allergy. 2000; 30(11):1540-46.

25. Saarinen KM, Suomalainen H, Savilahti E. Diagnostic value of skinprick and patch tests and serum eosinophil cationic protein and cow's milkspecific IgE in infants with cow's milk allergy. Clin Exp Allergy. 2001; 31(3):423-9.

26. Verstege A, Mehl A, Rolinck-Werninghaus C, Staden U, Nocon M, Beyer K, et al. The predictive value of the skin prick test weal size for the outcome of oral food challenges. Clin Exp Allergy. 2005; 35(9):1220-6.

27. Bock SA, Munoz-Furlong A, Sampson HA. Fatalities due to anaphylactic reactions to foods. J Allergy Clin Immunol. 2001; 107(1):191-3.

28. Bock SA. Diagnostic evaluation. Pediatrics. 2003; 111(6 Pt 3):1638-44.

29. Sampson HA, Albergo R. Comparison of results of skin tests, RAST, and double-blind, placebo-controlled food challenges in children with atopic dermatitis. J Allergy Clin Immunol. 1984; 74(1):26-33. 